\title{
Proposal to transfer some members of the genera Haemobartonella and Eperythrozoon to the genus Mycoplasma with descriptions of 'Candidatus Mycoplasma haemofelis', 'Candidatus Mycoplasma haemomuris', 'Candidatus Mycoplasma haemosuis' and 'Candidatus Mycoplasma wenyonii'
}

\footnotetext{
1 Department of Microbiology and Immunology, Box 44, College of Medicine, State University of New York, 450 Clarkson Avenue, Brooklyn, NY 11203, USA

2 Department of Bacteriology, National Veterinary Institute, SE-751 89 Uppsala, Sweden

3 Department of Veterinary Biosciences, College of Veterinary Medicine, The Ohio State University, Columbus, OH 43210, USA

4 Mycoplasma Section, Frederick Cancer Research and Development Center, National Institute of Allergy and Infectious Diseases, Frederick, MD 21707, USA
}

\author{
Harold Neimark, ${ }^{1}$ Karl-Erik Johansson, ${ }^{2}$ Yasuko Rikihisa ${ }^{3}$ \\ and Joseph G. Tully ${ }^{4}$ \\ Author for correspondence: Harold Neimark. Tel: +1 718270 1242. Fax: +1 7182702656 \\ e-mail: neimah25@hscbklyn.edu
}

\begin{abstract}
Cell-wall-less uncultivated parasitic bacteria that attach to the surface of host erythrocytes currently are classified in the order Rickettsiales, family Anaplasmataceae, in the genera Haemobartonella and Eperythrozoon. Recently $16 S$ rRNA gene sequences have been determined for four of these species: Haemobartonella felis and Haemobartonella muris and Eperythrozoon suis and Eperythrozoon wenyonii. Phylogenetic analysis of these sequence data shows that these haemotrophic bacteria are closely related to species in the genus Mycoplasma (class Mollicutes). These haemotrophic bacteria form a new phylogenetic cluster within the so-called pneumoniae group of Mycoplasma and share properties with one another as well as with other members of the pneumoniae group. These studies clearly indicate that the classification of these taxa should be changed to reflect their phylogenetic affiliation and the following is proposed: (i) that Haemobartonella felis and Haemobartonella muris should be transferred to the genus Mycoplasma as 'Candidatus Mycoplasma haemofelis' and 'Candidatus Mycoplasma haemomuris' and (ii) that Eperythrozoon suis and Eperythrozoon wenyonii should be transferred to the genus Mycoplasma as 'Candidatus Mycoplasma haemosuis' and 'Candidatus Mycoplasma wenyonii'. The former Haemobartonella and Eperythrozoon species described here represent a new group of parasitic mycoplasmas that possess a pathogenic capacity previously unrecognized among the mollicutes. These haemotrophic mycoplasmas have been given the trivial name haemoplasmas. These results call into question the affiliation of the remaining officially named species of Haemobartonella and Eperythrozoon which should be considered species of uncertain affiliation pending the resolution of their phylogenetic status.
\end{abstract}

Keywords: 16S rRNA, Rickettsiales, Anaplasmataceae, Mollicutes, phylogeny

The genera Haemobartonella and Eperythrozoon are composed of uncultivated haemotrophic bacterial

\footnotetext{
† Present address: 16400 Black Rock Road, Germantown, MD 20874-3212, USA.

The GenBank accession numbers for the 16S rDNA sequences are given in the species descriptions.
}

\section{INTRODUCTION}

01711 (C) 2001 IUMS species that infect the erythrocytes of a wide range of animal hosts (Kreier \& Ristic, 1984; Kreier et al., 1992; Tyzzer, 1942; Weinman, 1944). Microscopic examination of blood smears stained with Romanowsky-type stains show the presence of small coccoid, ring or rod-shaped structures on the surface of red cells (the rod-shaped structures probably are composed of coccoidal bodies since coccoidal bodies mainly have been observed by electron microscopy). 
The organisms stain blue to purple with WrightGiemsa stain; acridine orange staining may reveal the presence of these organisms when they are not demonstrated by Romanowsky-type staining procedures (Bobade \& Nash, 1987). These parasitic bacteria have not been cultivated in cell-free media and up to now have been maintained only by serial passage in animal hosts.

Many infections caused by Haemobartonella and Eperythrozoon are clinically inapparent but some species are pathogenic and cause overt disease in healthy, immunocompetent hosts. Clinical disease usually includes haemolytic anaemia which varies from mild to severe. Haemobartonella felis produces a severe, often fatal infectious anaemia in cats; mice inoculated with Haemobartonella muris frequently are killed; Eperythrozoon suis produces acute infections in pigs and anaemia with mortality in young pigs; and Eperythrozoon ovis can produce severe anaemia, poor weight gain and morbidity in lambs.

These bacteria can persist for years in latently infected animals without causing clinical disease. Apparently they are cleared from the circulation by sequestration in the spleen (Maede, 1979). Subjecting latently infected animals to splenectomy, stress or other predisposing factors often result in the appearance of large numbers of infected erythrocytes in the circulation; overt disease may also result. Haematologic detection of inapparent infections may require daily sampling for prolonged periods, but molecular diagnostic procedures should improve detection (Oberst et al., 1990, 1993; Gawaltny \& Oberst, 1994; Berent et al., 1998; Messick et al., 1999). Transmission frequently involves vectors and Haemobartonella and Eperythrozoon species have been shown to be transmitted by various blood-feeding arthropods, including ticks, lice, fleas, flies and mosquitoes.

Haemobartonella and Eperythrozoon species are currently classified as rickettsiae (order Rickettsiales) which they appeared to resemble because of their small size and staining properties, their uncultivated status, their transmission by arthropod vectors and their haemotrophic character (Kreier \& Ristic, 1984). The latter property seemed to relate these bacteria to Anaplasma (family Anaplasmataceae) which grow as inclusion bodies within erythrocytes; however Haemobartonella and Eperythrozoon differ from Anaplasma in that they are wall-less, attach to the surface of red cells and do not invade erythrocytes.

Until now, individual species were named after the host in which they were identified. Host range was considered a useful character for speciation because most organisms were thought to inhabit a single host. However, the impression of a single or primary host for each species may need to be modified since the host range of most species has not been fully examined. Eperythrozoon ovis for example, originally named after its sheep host, also infects goats.

The individual haemotrophic species have been assigned either to the genus Haemobartonella or Eperythrozoon on the basis of reports (i) that Eperythrozoon commonly occur as 'ring forms', while ring forms are rare or absent in Haemobartonella, and (ii) that Eperythrozoon occur with about equal frequency on erythrocytes and free in the plasma while Haemobartonella rarely occur free in plasma. We consider these characters for differentiating species of Haemobartonella and Eperythrozoon to be weak and agree with Kreier \& Ristic (1984) that the differentiation of species in these genera is arbitrary. The currently approved Haemobartonella and Eperythrozoon species and their recognized hosts are: Haemobartonella canis (dog), Haemobartonella felis (cat) and Haemobartonella muris (rodents), and Eperythrozoon coccoides (mouse), Eperythrozoon ovis (sheep), Eperythrozoon suis (pig) Eperythrozoon parvum (pig) and Eperythrozoon wenyonii (cattle).

More than 35 years ago Tanaka et al. (1965) showed by electron microscopy that Haemobartonella muris and Eperythrozoon coccoides lack cell walls and noted that these wall-less bacteria were indistinguishable from mycoplasmas. Subsequently, all the other Haemobartonella and Eperythrozoon species described in Bergey's manual also were shown by electron microscopy to lack cell walls.

Recently, four of these wall-less haemotrophic bacteria, Haemobartonella felis, Haemobartonella muris, Eperythrozoon suis and Eperythrozoon wenyonii, have been subjected to phylogenetic investigation and their 16S rRNA gene sequences have been published (Rikihisa et al., 1997; Neimark \& Kocan, 1997). The data from these studies demonstrate clearly that these bacteria are not phylogenetically related to rickettsiae but instead that their closest relatives are species in the genus Mycoplasma. These data also affirm that each of these haemotrophic bacteria is a valid species. Thus, these representatives of the genera Haemobartonella and Eperythrozoon are in fact members of a single genus, Mycoplasma (Rikihisa et al., 1997; Neimark \& Kocan, 1997; Johansson et al., 1999). The results do not support the current classification of these species as rickettsiae and indicate that the classification of these taxa should be changed. We propose the following: (i) that the described Haemobartonella species should be removed from the order Rickettsiales, family Anaplasmataceae, and transferred to the genus Mycoplasma as 'Candidatus Mycoplasma haemofelis' and 'Candidatus Mycoplasma haemomuris' and (ii) that the described Eperythrozoon species should be removed from the order Rickettsiales, family Anaplasmataceae, and transferred to the genus Mycoplasma as 'Candidatus Mycoplasma haemosuis' and 'Candidatus Mycoplasma wenyonii'.

\section{METHODS}

Phylogenetic analysis. The $16 \mathrm{~S}$ rRNA gene sequences were aligned manually by using Genetic Data Environment software (Smith, 1992). The phylogenetic tree was con- 


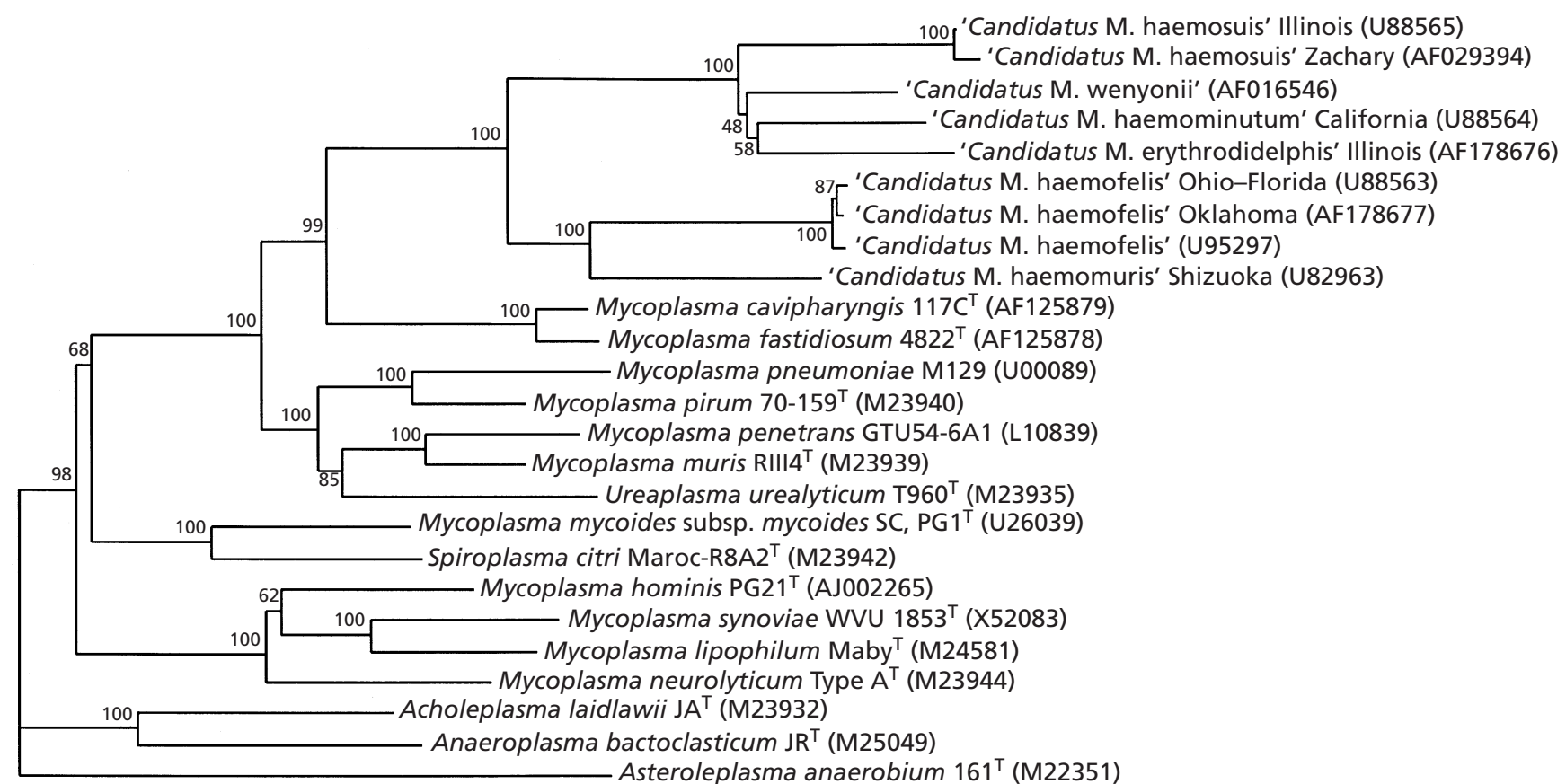

$0 \cdot 10$

Fig. 1. Phylogenetic tree based on sequence analysis of $16 \mathrm{~S}$ rRNA genes showing the relationship between haemoplasmas and other members of the pneumoniae group as well as other members of the class Mollicutes. Asteroleplasma anaerobium was used as outgroup. Bootstrap percentage values are given at the nodes of the tree and the scale bar shows the distance equivalent to 1 substitution per $10 \mathrm{nt}$.

structed by using the algorithms implemented in the phylogenetic program package PHYLIP (Felsenstein, 1993). The tree was computed by using the neighbour-joining program (Saitou \& Nei, 1987) from a distance matrix corrected for nucleotide substitutions by the Kimura two-parameter model (Kimura, 1980) with a transition/transversion ratio set at 2. The data set was resampled 1000 times and the bootstrap percentage values are given at the nodes of the phylogenetic tree shown in Fig. 1.

\section{RESULTS AND DISCUSSION}

\section{Phylogeny of the haemotrophic mycoplasmas}

A phylogenetic tree (Fig. 1) shows that all the Haemobartonella and Eperythrozoon species for which 16S rDNA sequences have been determined cluster together on a single branch and that the branch is located within the so-called pneumoniae group of the genus Mycoplasma (Neimark \& Kocan, 1997; Johansson et al., 1999). The $16 \mathrm{~S}$ rRNA sequences used in this work had been determined earlier and were retrieved from GenBank. The phylogenetic analysis and results are similar to those obtained in a previous study (Johansson et al., 1999), but additional recently identified organisms were included in the current investigation. This tree was obtained from the $16 \mathrm{~S}$ rRNA gene sequence alignment of all nucleotides between the positions corresponding to positions 69-1441 in Escherichia coli and has essentially the same topology as previously published 16S rRNAbased trees of haemotrophic mycoplasmas (Neimark \& Kocan, 1997; Johansson et al., 1999). Note that Haemobartonella felis California in the previous studies (Neimark \& Kocan, 1997; Johansson et al., 1999) now is designated 'Candidatus Mycoplasma haemominutum' (Foley \& Pedersen, 2001) in Fig. 1, but the names correspond to the same GenBank accession number (U88564). As before, the tree reveals two subclusters of organisms. These subclusters are supported also by a characteristic truncation of about $10 \mathrm{bp}$ in a segment corresponding to positions 453-481 in the 16S rRNA sequence of Escherichia coli (Johansson et al., 1999) which was found to be present in all 'Candidatus Mycoplasma haemofelis' strains and in 'Candidatus Mycoplasma haemomuris' Shizuoka (the haemofelis subcluster), but absent from organisms in the other cluster (the haemosuis subcluster). A similar tree was obtained when about 150 ambiguously aligned positions and gaps were removed from the alignment. However, in this case a different branching order was obtained for the members of the haemosuis subcluster, but the bootstrap values for this subcluster were significantly lower when the latter alignment was used for phylogenetic analysis (data not shown).

We propose to formally recognize these phylogenetic relations and move these species to the genus $\mathrm{Myco-}$ 
plasma. For continuity and to avoid confusion, rickettsial species names have been retained where there is not a conflict with existing Mycoplasma species names; for example the species name wenyonii has been retained (Neimark \& Kocan, 1997). In contrast, both rickettsia and mycoplasmas contain the species names felis, muris and suis and we considered that proposing completely new species names for these bacteria would lead to confusion. Since the term 'haemotrophic bacteria' has been used widely in the literature, we selected the short prefix haemo to form the combination species names haemofelis, haemomuris and haemosuis. We have given the haemotrophic mycoplasmas the trivial name haemoplasmas.

Taxonomic descriptions of the proposed species are given at the end of this paper. Haemobartonella felis, Haemobartonella muris, Eperythrozoon suis and Eperythrozoon wenyonii were each validly published species according to criteria in use at the time of their discovery. We have adopted the Candidatus status for both the previously named species and newly identified bacteria, even though this constitutes a taxonomic demotion of these four species; however, we think this uniform treatment is justified since it provides for consistent descriptions of all uncultivated haemotrophic mycoplasmas. Otherwise, an artificial taxonomic distinction would be created between those organisms that were discovered before and those discovered after the development of molecular methods for characterizing bacteria.

The remaining officially named species of Haemobartonella and Eperythrozoon also are wall-less and all share identical properties with the haemotrophic Mycoplasma species described here, so it seems likely that they too will be found to be mycoplasmas. Already, Eperythrozoon ovis has been identified as a distinct Mycoplasma species (H. Neimark, B. Hoff \& M. Ganter, unpublished). Nonetheless, we shall consider the remaining bacteria contained in the genera Haemobartonella and Eperythrozoon to be species of uncertain affiliation pending determination of their actual phylogenetic position.

Over the years, numerous reports have described erythrocytic bodies resembling Haemobartonella and Eperythrozoon in a wide variety of vertebrate animals (Weinman, 1944; Kreier \& Ristic, 1968; Kreier et al., 1981). In many instances these bodies were given species names merely on the basis of observing structures in stained blood smears. Careful evaluation of blood smears is required to distinguish these bacteria from erythrocytic structures such as Pappenheimer bodies, Heinz bodies, Howell-Jolly bodies or other structures, and it may be difficult to differentiate haemotrophic mycoplasmas from basophilic structures without the aid of molecular diagnostic methods or electron microscopy. In several cases the erythrocytic bodies were critically examined and shown by electron microscopy to be wall-less bacteria; also in some cases, animal transmission and culture studies were attempted. Erythrocytic bodies identified by electron microscopy as wall-less Eperythrozoon or Haemobartonella have been described in a raccoon (Frerichs \& Holbrook, 1971), llamas (McLaughlin et al., 1990, 1991; Reagan et al., 1990) and various monkey species (Aikawa \& Nussenzweig, 1974; Peters et al., 1973, 1974; Adams et al., 1984; Dilberger et al., 1994; Contamin \& Michel, 1999). One of these bacteria, an agent in the South American monkey Saimiri sciureus, has been identified as a new haemotrophic Mycoplasma species $(\mathrm{H}$. Neimark \& H. Contamin, unpublished) and others probably represent new haemotrophic Mycoplasma species or new hosts for known haemotrophic Mycoplasma species. Another haemotrophic Mycoplasma species has been identified in an opossum (GenBank accession no. AF178676; Messick et al., 2000).

Newly identified uncultivated haemotrophic Mycoplasma species should be proposed as Candidatus species (Murray \& Schleifer, 1994; Murray \& Stackebrandt, 1995) and the required information for this taxonomic entity should be provided.

Until now, mycoplasmas infecting vertebrates appeared to parasitize only the mucous membranes of their hosts; at these sites pathogenic mycoplasmas cause respiratory or urogenital disease, often with an arthritic component. The former Haemobartonella and Eperythrozoon species described here represent a new group of parasitic mycoplasmas that possess a pathogenic capacity previously unrecognized among the mollicutes. Recognition that these haemotrophic bacteria are mycoplasmas provides an entirely new perspective for undertaking their study.

\section{Properties of haemotrophic mycoplasmas}

Haemotrophic mycoplasmas share some significant properties with other members of the pneumoniae group. (i) Some members of the pneumoniae group possess tip or bleb structures which are involved in host-cell attachment; a similar bleb structure has been observed in the mycoplasma from the South American monkey Saimiri sciureus (Aikawa \& Nussenzweig, 1972; Adams et al., 1984) and in the agent from the owl monkey Aotus trivirgatus (Peters et al., 1974). (ii) At least three haemotrophic bacteria (Haemobartonella canis, 'Candidatus Mycoplasma haemofelis' and 'Candidatus Mycoplasma haemosuis') share with Mycoplasma pneumoniae the capability to induce cold agglutinins in hosts. It is known that Mycoplasma pneumoniae can enter the blood circulation and also has the capacity to bind to red blood cells in vitro. Whether Mycoplasma pneumoniae binds to erythrocytes in vivo in a manner similar to the haemotrophic mycoplasmas is being examined.

The surface components of haemotrophic mycoplasmas involved in erythrocyte adherence have not been identified. Many of these agents produce an 
indentation on the red-cell membrane at the site of attachment (Tanaka et al., 1965; Adams et al., 1984; Neimark \& Kocan, 1997; Rikihisa et al., 1997) and also in some, fine fibrils can be seen connecting the bacteria and the erythrocytes (Peters et al., 1974; Zachary \& Basgall, 1985). Experiments with lectins in 'Candidatus Mycoplasma wenyonii' infection have suggested that the erythrocyte membrane is altered as shown by increased recognition of both soybean agglutinin and peanut agglutinin receptor carbohydrates (Goff et al., 1986). Haemotrophic mycoplasmas can readily be dissociated from erythrocytes by gently shaking infected erythrocytes either at room temperature in $0 \cdot 15 \mathrm{M}$ PBS, $\mathrm{pH} 7 \cdot 2$, containing $0 \cdot 15 \%$ Tween-20 and 1\% EDTA (Hall et al., 1988; see also Lang et al., 1986) or at $37^{\circ} \mathrm{C}$ in PBS (Rikihisa et al., 1997).

Little is known about the metabolism of these uncultivated mycoplasmas but Smith et al. (1990) observed that glucose consumption by red cells infected by Eperythrozoon suis ('Candidatus Mycoplasma haemosuis') is inhibited by iodoacetate and by sodium fluoride, and suggested that this bacterium is responsible for the glucose consumption and that it metabolizes glucose by glycolysis; lactate may be the major end product of glycolysis (Nonaka et al., 1996). This metabolic pattern would be consistent with that of fermentative mollicutes (Neimark, 1979).

Although these bacteria appear to be obligately parasitic organisms, their identification as mycoplasmas provides new insight for undertaking in vitro cultivation. For most purposes, blood is best collected with citrate as the anticoagulant since these bacteria lose infectivity when collected with EDTA (Hall et al., 1988) and heparin interferes with the PCR. DNA from organisms in blood is well preserved on FTA blood cards (Fitzco) (H. Neimark \& M. Ganter, unpublished). Infected blood has been cryopreserved by adding $40 \%$ polyvinyl pyrrolidone $(6.7 \%$ final concn) $/ 10 \%$ glycerol and freezing in liquid nitrogen (Nonaka et al., 1996); dimethylsulfoxide also has been used for cryopreservation but $10 \%$ glycerol $/ 10 \%$ horse serum commonly used for preserving mycoplasmas at $-70{ }^{\circ} \mathrm{C}$ may be adequate. The conditions for in vitro maintenance of 'Candidatus Mycoplasma haemosuis' described by Nonaka et al. (1996) probably would be useful for other haemotrophic mycoplasmas and information about mycoplasma physiology and genetics should be applicable as well.

Transmission by blood-feeding vectors may result in cross-infection between domestic and wild animal populations, and possibly humans, and the host ranges of these bacteria needs to be investigated. There have been reports of apparently related haemotrophic bacteria from human cases (H. Neimark, unpublished), some of which were demonstrated to be wall-less bacteria by electron microscopic studies (Clark, 1975; Duarte et al., 1992). Thus, it appears that a number of additional new haemotrophic Mycoplasma species remain to be identified and that haemotrophic mycoplasmas will comprise a large cluster within the pneumoniae group.

\section{Species descriptions}

Based on the literature and our observations, the haemotrophic Mycoplasma species share the following characters: all of the species described parasitize the erythrocytes of their hosts and adhere to the erythrocyte surface, often in an indentation or deformation of the erythrocyte membrane; all have been shown by electron microscopy to lack a cell wall and to be coccoidal in shape, usually with a diameter of less than $0.9 \mu \mathrm{m}$, and all are uncultivated in vitro. These bacteria are observed in blood smears with Romanowsky-type stains (Wright-Giemsa stain is particularly suitable) or with greater sensitivity by fluorescent staining. The number of infected red cells can range from just detectable to more than $80 \%$ infected and individual erythrocytes can carry many organisms. Arthropod transmission of most of these species has been demonstrated. All species that have been examined are sensitive to tetracycline but are resistant to penicillin and other antimicrobial agents that target the bacterial cell wall.

\section{Description of 'Candidatus Mycoplasma haemofelis' (basonym Haemobartonella felis (ex Flint and McKeelvie 1956) nom. rev. (Eperythrozoon felis Clark 1942)}

'Candidatus Mycoplasma haemofelis' (hae.mo.fe'lis. Gr. neut. n. haema blood; L. fem. gen. n. felis of the cat; M.L. fem. gen. n. haemofelis of cat blood).

A parasite of the domestic cat and the agent of feline infectious anaemia, a severe sometimes fatal anaemia. Cells are coccoid but may appear as chains or short rods in stained smears. The large form described by Foley et al. (1998) is typical of this species. 'Candidatus Mycoplasma haemofelis' is prominent among the haemotrophic mycoplasmas because it produces a patent parasitaemia and severe, sometimes fatal, anaemia and illness in intact animals under field conditions. Attachment of two or more erythrocytes to a common organism brings about erythrocyte sequestration in blood capillaries (Simpson et al., 1978). Cold agglutinins may be detected during the acute stage of anaemia (Zulty \& Kociba, 1990). Splenectomy has relatively little effect on the course of the infection (Splitter et al., 1956). The disease has been produced in susceptible cats by inoculations of pooled blood from clinically normal cats (Splitter et al., 1956), thus indicating that infection can produce a carrier state as well as patent disease. The infection can be transmitted by intraperitoneal, intravenous or oral routes (Flint et al., 1959) and may be transmitted by biting during cat fights; vertical transmission may occur (Harbutt, 1963; Fisher, 1983). Vector transmission has not been established, but the cat flea is thought to be a vector. 
Table 1. Distinct haemotrophic Mycoplasma species from cats

\begin{tabular}{|c|c|c|c|}
\hline Organism & Clinical signs & Representative strain & GenBank accession no. or sequence \\
\hline \multirow[t]{3}{*}{$\begin{array}{l}\text { Large-form* 'Candidatus Mycoplasma } \\
\text { haemofelis', the agent of feline } \\
\text { infectious anaemia }\end{array}$} & $\begin{array}{l}\text { Severe anaemia, fever, } \\
\text { depression and anorexia; } \\
\text { dyspnea }\end{array}$ & Large-form* & $\begin{array}{l}\text { Sequence reported to be } 99 \% \\
\text { similar to Illinois (U95297)* }\end{array}$ \\
\hline & & Ohio-Florida $\uparrow$ & $\mathrm{U} 88563 \dagger$ \\
\hline & & Illinois, Oklahomat & $\begin{array}{l}\text { U95297 and AF178677\$ } \\
\text { sequences are } 98 \text { and } 99 \% \\
\text { similar to Ohio-Florida, } \\
\text { respectively, and } 99 \% \\
\text { similar to one another§ }\end{array}$ \\
\hline \multirow[t]{2}{*}{$\begin{array}{l}\text { Small-form* 'Candidatus Mycoplasma } \\
\text { haemominutum' }\end{array}$} & $\begin{array}{l}\text { Clinical signs mild } \\
\text { or absent }\end{array}$ & Small-form* & $\begin{array}{l}\text { Sequence reported* to be } \\
\text { identical to California (U88564) }\end{array}$ \\
\hline & & California $\dagger$ & $\mathrm{U} 88564 \dagger$ \\
\hline
\end{tabular}

* Foley et al. (1998).

$\dagger$ Rikihisa et al. (1997).

† Strain sequences submitted to GenBank by Messick et al. (1998, 1999).

$\S$ Percentage values determined from BLAST (Altschul et al., 1990) sequence matches.

According to Splitter et al. (1956), this organism is not infective for rats, mice, swine, cattle, sheep or dogs. A PCR-based detection assay (Berent et al., 1998) and a hybridization probe (Berent et al., 2000) have been described. Chloramphenicol, tetracycline and oxytetracycline are effective in suppressing infection.

Three 16S rRNA gene sequences have been deposited in the GenBank database under accession numbers U88563 (Rikihisa et al., 1997), U95297 (J. B. Messick and others) and AF178677 (L. M. Berent \& J. B. Messick). The sequence AF178677 is $99 \%$ similar to U88563 and U95297 while the latter two sequences are $98 \%$ similar to one another. PCR primers for amplification of a segment of the 16S rRNA gene have been described (Berent et al., 1998).

'Candidatus Mycoplasma haemofelis' may be able to infect splenectomized dogs since the 16S rRNA gene sequence of a Haemobartonella canis strain (GenBank AF197337) is $99.4 \%$ identical to the sequence of a virulent cat strain (J. B. Messick, personal communication). Haemobartonella canis reportedly produces a severe anaemia in dogs and has been described frequently, usually after splenectomy, but infection in non-splenectomized dogs can occur (Austerman, 1979) and North (1978) has reported a fatal case. Lumb (1961) has stated that cats remain asymptomatic when inoculated with blood from a dog with canine haemobartonellosis and that blood from these cats when inoculated into dogs reproduces the disease.

Note that a second distinct haemotrophic Mycoplasma species occurs in cats. In early studies two morphologic and staining types of Haemobartonella felis were described in cats (Splitter et al., 1956). Recently, Foley et al. (1998) distinguished, in addition to the former
Haemobartonella felis, a low-virulence, small-form haemotrophic bacterium as a second cat species; this haemotrophic bacterium has a $16 \mathrm{~S}$ rRNA gene sequence identical to the sequence published by Rikihisa et al. (1997) for Haemobartonella felis California (GenBank accession no. U88564). The cat small-form species represented by the California strain is distinct from 'Candidatus Mycoplasma haemofelis' (see Table 1) and is more closely related to 'Candidatus Mycoplasma erythrodidelphis', 'Candidatus Mycoplasma haemosuis' and 'Candidatus Mycoplasma wenyonii' than to 'Candidatus Mycoplasma haemofelis' (Fig. 1). Foley has published a description of the cat small-form as 'Candidatus Mycoplasma haemominutum' (Foley \& Pedersen, 2001).

\section{Description of ' Candidatus Mycoplasma haemomuris' (basonym Haemobartonella muris Mayer 1921)}

'Candidatus Mycoplasma haemomuris' (hae.mo. mu'ris. Gr. neut. n. haema blood; L. masc. gen. n. muris of the mouse; M.L. masc. gen. n. haemomuris of mouse blood).

In Romanowsky-stained blood films, the organisms are coccoid and vary in diameter from 0.3 to $0.7 \mu \mathrm{m}$. They may contain dense inclusion particles in the cytoplasm (Tanaka et al., 1965). Causes infections in albino rats, albino mice, some wild mice and hamsters. Exposure to this agent produces either lethal disease or a carrier state. The determining factors are not all known, but splenectomized or young animals are more likely to develop patent infection than intact or mature animals. Latent infections may become patent following splenectomy or other processes that alter the immune functions of the host. Susceptible to chlor- 
tetracycline and oxytetracycline; these compounds will destroy the organisms in the host in both latent and clinical infections. 'Candidatus Mycoplasma haemomuris' occurs worldwide. The rat louse (Polypax spinulosa) is a vector. The 16S rRNA gene sequence has been deposited in the GenBank database under accession number U82963 and PCR primers for 16S rRNA gene amplification have been described (Rikihisa et al. 1997).

\section{Description of 'Candidatus Mycoplasma haemosuis' (basonym Eperythrozoon suis Splitter 1950)}

'Candidatus Mycoplasma haemosuis' (hae.mo.su'is. Gr. neut. n. haema blood; L. gen. n. suis of the pig; M.L. gen. n. haemosuis of pig blood).

The causative agent of icteroanaemia in swine (Splitter, 1950, 1963). This species has been described as the largest of these haemotrophic bacteria (Kreier \& Ristic, 1984). Cold agglutinins have been reported (Zulty \& Kociba, 1990; Schmidt et al., 1992). Splenectomy reportedly causes relapse in carrier pigs and an unusually high parasitaemia occurs in pigs splenectomized before infection (Splitter, 1950). ELISA (Hsu et al., 1992) and PCR-based detection assays (Oberst et al., 1993; Messick et al., 1999) have been described for diagnosis of infections caused by 'Candidatus Mycoplasma haemosuis'. Mechanical transmission by the stable fly (Stomoxys calcitrans) and the mosquito (Aedes aegypti) has been demonstrated (Prullage et al., 1993). The agent is sensitive to tetracyclines. The organism is common throughout the United States. The 16S rRNA gene sequence of 'Candidatus Mycoplasma haemosuis' from Taiwan is identical to that of 'Candidatus Mycoplasma haemosuis' from Illinois (Rikihisa et al., 1997). The large diameter of 'Candidatus Mycoplasma haemosuis' permits differentiation in stained blood smears from Eperythrozoon parvum, a non-pathogenic parasite of the pig. Two 16S rRNA gene sequences which are $99 \%$ identical have been deposited in the GenBank database under accession numbers U88565 (Rikihisa et al., 1997) and AF029394 (Messick et al., 1999). PCR primers for 16S rRNA gene amplification have been described (Rikihisa et al., 1997; Messick et al., 1999).

\section{Description of 'Candidatus Mycoplasma wenyonii' (basonym Eperythrozoon wenyonii Adler and Ellenbogen 1934)}

'Candidatus Mycoplasma wenyonii' (wen.yo'ni.i. M.L. gen. n. wenyonii of Wenyon, named after Dr C. M. Wenyon, an investigator of these organisms).

A parasite of cattle. Occurs attached to erythrocytes and may also be free in the plasma; a number of bodies can be attached to a single erythrocyte. These bacteria adhere to erythrocytes which usually show a small indentation at the site of attachment. According to Kreier \& Ristic (1968), occasionally may be observed attached to platelets. [An unidentified but possibly related micro-organism with an affinity for platelets was observed in Giemsa-stained blood smears from a splenectomized calf (Toumi \& Von Bonsdorff, 1967).] Organism produces parasitaemia and a mild anaemia. Infected cattle rarely die or show marked illness but occasionally may show acute clinical signs (Smith et al., 1990). Latent infection may be revealed by splenectomy and or by concurrent infection with Anaplasma. Infection with 'Candidatus Mycoplasma wenyonii' may be produced by parenteral injection of blood from a latently or patently infected animal. Vector transmission by the tick Dermacentor andersoni has been demonstrated. Not infective for sheep, goats or deer (Odocoileus virginiana). 'Candidatus Mycoplasma wenyonii' shares antigens with Eperythrozoon ovis, Anaplasma marginale and Anaplasma ovis. The organism occurs worldwide. Sensitive to tetracyclines. The 16S rRNA gene sequence has been deposited in the GenBank database under accession number AF016546 and PCR primers for 16S rRNA gene amplification have been described (Neimark \& Kocan, 1997).

\section{REFERENCES}

Adams, M. R., Lewis, J. C. \& Bullock, B. C. (1984). Hemobartonellosis in squirrel monkeys (Saimiri sciureus) in a domestic breeding colony: case report and preliminary study. Lab Anim Sci 34, 82-85.

Aikawa, M. \& Nussenzweig, R. (1972). Fine structure of Haemobartonella sp. in the squirrel monkey. J Parasitol 58, 628-630.

Altschul, S. F., Gish, W., Miller, W., Myers, E. W. \& Lipman, D. J. (1990). Basic local alignment search tool. J Mol Biol 215, 403-410.

Austerman, J. W. (1979). Haemobartonellosis in a nonsplenectomized dog. Vet Med Small Anim Clin 74, 954.

Berent, L. M., Messick, J. B. \& Cooper, S. K. (1998). Detection of Haemobartonella felis in cats with experimentally induced acute and chronic infections, using a polymerase chain reaction assay. Am J Vet Res 59, 1215-1220.

Berent, L. M., Messick, J. B., Cooper, S. K. \& Cusick, P. K. (2000). Specific in situ hybridization of Haemobartonella felis with a DNA probe and tyramide signal amplification. Vet Pathol 37, 47-53.

Bobade, P. A. \& Nash, A. S. (1987). A comparative study of the efficiency of acridine orange and some Romanowsky staining procedures in the demonstration of Haemobartonella felis in feline blood. Vet Parasitol 26, 169-172.

Clark, K. G. A. (1975). A basophilic micro-organism infecting human red cells. Br J Haematol 29, 301-304.

Contamin, H. \& Michel, J. C. (1999). Haemobartonellosis in squirrel monkeys (Saimiri sciureus): antagonism between Haemobartonella sp. and experimental Plasmodium falciparum malaria. Exp Parasitol 91, 297-305.

Dillberger, J. E., Loudy, D. E., Adler, R. R. \& Gass, J. H. (1994). Haemobartonella-like parasites in cynomolgus monkeys (Macaca fascicularis). Vet Pathol 31, 301-307.

Duarte, M. I., Oliveira, M. S., Shikanai-Yasuda, M. A., Mariano, O. N., Takakura, C. F., Pagliari, C. \& Corbett, C. E. (1992). 
Haemobartonella-like microorganism infection in AIDS patients: ultrastructural pathology. J Infect Dis 165, 976-977.

Felsenstein, J. (1993). PHYLIP (Phylogeny Inference Package) version 3.52. Seattle: Department of Genetics, University of Washington.

Fisher, E. (1983). Anemia in a litter of Siamese kittens. J Small Anim Pract 24, 215-219.

Flint, J., Roepke, M. \& Jensen, R. (1959). Feline infectious anemia. II. Experimental cases. Am J Vet Res 20, 33-40.

Foley, J. E. \& Pedersen, N. C. (2001). 'Candidatus Mycoplasma haemominutum', a low-virulence epierythrocytic parasite of cats. Int J Syst Evol Microbiol 51, 815-817.

Foley, J. E., Harrus, S., Poland, A., Chomel, B. \& Pedersen, N. C. (1998). Molecular, clinical, and pathologic comparison of two distinct strains of Haemobartonella felis in domestic cats. Am J Vet Res 59, 1581-1588.

Frerichs, W. M. \& Holbrook, A. A. (1971). Haemobartonella procyoni sp. nov. in the raccoon, Procyon coton. J Parasitol 57, $1309-1310$

Goff, W. L., Johnson, L. W. \& Kuttler, K. L. (1986). Anaplasma marginale, Eperythrozoon wenyoni: lectin reactions with bovine erythrocytes. Exp Parasitol 61, 103-113.

Gwaltney, S. M. \& Oberst, R. D. (1994). Comparison of an improved polymerase chain reaction protocol and the indirect hemagglutination assay in the detection of Eperythrozoon suis infection. $J$ Vet Diagn Invest 6, 321-325.

Hall, S. M., Cipriano, J. A., Schoneweis, D. A., Smith, J. E. \& Fenwick, B. W. (1988). Isolation of infective and non-infective Eperythrozoon suis bodies from the whole blood of infected swine. Vet Rec 123, 651.

Harbutt, P. A. (1963). A clinical appraisal of feline infectious anemia and its transmission under natural conditions. Aust Vet $J$ 39, 402-404.

Hsu, F. S., Liu, M. C., Chou, S. M., Zachary, J. F. \& Smith, A. R. (1992). Evaluation of an enzyme-linked immunosorbent assay for detection of Eperythrozoon suis antibodies in swine. Am J Vet Res 53, 352-354.

Johansson, K. E., Tully, J. G., Bolske, G. \& Pettersson, B. (1999). Mycoplasma cavipharyngis and Mycoplasma fastidiosum, the closest relatives to Eperythrozoon spp. and Haemobartonella spp. FEMS Microbiol Lett 174, 321-326.

Kimura, M. (1980). A simple method for estimating evolutionary rate of base substitutions through comparative studies of nucleotide sequences. J Mol Evol 16, 111-120.

Kreier, J. P. \& Ristic, M. (1968). Haemobartonellosis, Eperythrozoonosis, Grahamellosis, and Ehrlichiosis. In Infectious Blood Diseases of Man and Animals, vol. II, pp. 387-472. Edited by D. Weinman \& M. Ristic. New York: Academic Press.

Kreier, J. P. \& Ristic, M. (1984). Genus III Haemobartonella; Genus IV Eperythrozoon. In Bergey's Manual of Systematic Bacteriology, vol. 1, pp. 724-729. Edited by N. R. Krieg \& J. G. Holt. Baltimore, MD: Williams \& Wilkins.

Kreier, J. P., Dominquez, N., Krampitz, H. E., Gothe, R. \& Ristic, M. (1981). The Hemotrophic Bacteria: the Families Bartonellaceae and Anaplasmataceae. In The Prokaryotes vol. 2, pp. 2189-2209. Edited by M. P. Starr, H. Stolp, H. G. Trüper, A. Balows \& H. G. Schlegel. Berlin: Springer.

Kreier, J. P., Gothe, R., Ihler, G. M., Krampitz, H. E., Mernaugh, G. \& Palmer, G. H. (1992). The Hemotrophic Bacteria: the Families Bartonellaceae and Anaplasmataceae. In The Prokaryotes vol. 4, pp. 3994-4022. Edited by A. Balows, H. G. Trüper, M. Dworkin, W. Harder \& H.-K. Schleifer. Berlin: Springer.
Lang, F. M., Ferrier, G. R. \& Nicholls, T. J. (1986). Separation of Eperythrozoon ovis from erythrocytes. Vet Rec 119, 359.

Lumb, W. V. (1961). Canine haemobartonellosis and its feline counterpart. Calif Vet 14, 24.

McLaughlin, B. G., Evans, C. N., McLaughlin, P. S., Johnson, L. W., Smith, A. R. \& Zachary, J. F. (1990). An Eperythrozoon-like parasite in llamas. J Am Vet Med Assoc 197, 1170-1175.

McLaughlin, B. G., McLaughlin, P. S. \& Evans, C. N. (1991). An Eperythrozoon-like parasite of llamas: attempted transmission to swine, sheep, and cats. J Vet Diagn Invest 3, 352-353.

Maede, Y. (1979). Sequestration and phagocytosis of Haemobartonella felis in the spleen. Am J Vet Res 40, 691-695.

Messick, J. B., Berent, L. M. \& Cooper, S. K. (1998). Development and evaluation of a PCR-based assay for detection of Haemobartonella felis in cats and differentiation of $H$. felis from related bacteria by restriction fragment length polymorphism analysis. $J$ Clin Microbiol 36, 462-466.

Messick, J. B., Cooper, S. K. \& Huntley, M. (1999). Development and evaluation of a polymerase chain reaction assay using the 16S rRNA gene for detection of Eperythrozoon suis infection. $J$ Vet Diagn Invest 11, 229-236.

Messick, J. B., Berent, L. M., Ehrhart, E. J. \& Wasmer, C. C. (2000). Light and electron microscopic features of eperythrozoon-like parasites in a North American opossum. J Zoo Wildl Med 31, 240-243.

Murray, R. G. \& Schleifer, K. H. (1994). Taxonomic notes: a proposal for recording the properties of putative taxa of procaryotes. Int J Syst Bacteriol 44, 174-176.

Murray, R. G. \& Stackebrandt, E. (1995). Taxonomic note: implementation of the provisional status Candidatus for incompletely described procaryotes. Int $J$ Syst Bacteriol 45, 186-187.

Neimark, H. (1979). Phylogenetic relationships between mycoplasmas and other prokaryotes. In The Mycoplasmas, pp. 43-61. New York: Academic Press.

Neimark, H. \& Kocan, K. M. (1997). The cell wall-less rickettsia Eperythrozoon wenyonii is a mycoplasma. FEMS Microbiol Lett 156, 287-291.

Nonaka, N., Thacker, B. J., Schillhorn van Veen, T. W. \& Bull, R. W. (1996). In vitro maintenance of Eperythrozoon suis. Vet Parasitol 61, 181-199.

North, D. C. (1978). Fatal haemobartonellosis in a non-splenectomized dog - a case report. J Small Anim Pract 19, 769-773.

Oberst, R. D., Hall, S. M., Jasso, R. A., Arndt, T. \& Wen, L. (1990). Recombinant DNA probe detecting Eperythrozoon suis in swine blood. Am J Vet Res 51, 1760-1764.

Oberst, R. D., Gwaltney, S. M., Hays, M. P., Morgan, S. \& Stair, E. L. (1993). Experimental infections and natural outbreaks of eperythrozoonosis in pigs identified by PCR-DNA hybridizations. J Vet Diagn Invest 5, 351-358.

Peters, W., Howells, R. E. \& Molyneux, D. H. (1973). Eperythrozoon and Haemobartonella in primates. Trans $R$ Soc Trop Med Hyg 67, 21.

Peters, W., Molyneux, D. H. \& Howells, R. E. (1974). Eperythrozoon and Haemobartonella in monkeys. Ann Trop Med Parasitol 68, 47-50.

Prullage, J. B., Williams, R. E. \& Gaafar, S. M. (1993). On the transmissibility of Eperythrozoon suis by Stomoxys calcitrans and Aedes aegypti. Vet Parasitol 50, 125-135.

Reagan, W. J., Garry, F., Thrall, M. A., Colgan, S., Hutchison, J. \& Weiser, M. G. (1990). The clinicopathologic, light, and scanning 
electron microscopic features of eperythrozoonosis in four naturally infected llamas. Vet Pathol 27, 426-431.

Rikihisa, Y., Kawahara, M., Wen, B., Kociba, G., Fuerst, P., Kawamori, F., Suto, C., Shibata, S. \& Futohashi, M. (1997). Western immunoblot analysis of Haemobartonella muris and comparison of $16 \mathrm{~S}$ rRNA gene sequences of $H$. muris, $H$. felis, and Eperythrozoon suis. J Clin Microbiol 35, 823-829.

Saitou, N. \& Nei, M. (1987). The neighbor-joining method: a new method for reconstructing phylogenetic trees. Mol Biol Evol 4, 406-425.

Schmidt, P., Kaspers, B., Jungling, A., Heinritzi, K. \& Losch, U. (1992). Isolation of cold agglutinins in Eperythrozoon suisinfected pigs. Vet Immunol Immunopathol 31, 195-201.

Simpson, C. F., Gaskin, J. M. \& Harvey, J. W. (1978). Ultrastructure of erythrocytes parasitized by Haemobartonella felis. $J$ Parasitol 64, 504-511.

Smith, J. A., Thrall, M. A., Smith, J. L., Salman, M. D., Ching, S. V. \& Collins, J. K. (1990). Eperythrozoon wenyonii infection in dairy cattle. J Am Vet Med Assoc 196, 1244-1250.

Smith, J. E., Cipriano, J. E. \& Hall, S. M. (1990). In vitro and in vivo glucose consumption in swine eperythrozoonosis. Zentbl Vetmed Reihe B 37, 587-592.

Smith, S. (1992). Genetic Data Environment (Version 2.2). Millipore Imaging Systems, Ann Arbor, MI

Splitter, E. J. (1950). Eperythrozoon suis n. sp. and Eperythrozoon parvum n. sp., two new blood parasites of swine. Science 111, 513-514.

Splitter, E. J. (1963). Eperythrozoon suis, the etiological agent of ictero-anemia or an anaplasmosis-like disease in swine. Am J Vet Res 11, 324-330.

Splitter, E., Castro, E. \& Kanawyer, W. (1956). Feline infectious anemia. Vet Med 51, 17-22.

Tanaka, H., Hall, W. T., Sheffield, J. B. \& Moore, D. H. (1965). Fine structure of Haemobartonella muris as compared with Eperythrozoon coccoides and Mycoplasma pulmonis. J Bacteriol 90, 1735-1749.

Tuomi, J. \& Von Bonsdorff, C. H. (1967). Ultrastructure of a microorganism associated with bovine platelets. Experientia $\mathbf{2 3}$, 111-112.

Tyzzer, E. E. (1942). A comparative study of Grahamellae, Haemobartonellae and Eperythrozoa in small mammals. Proc Am Philos Soc 85, 359-398.

Weinman, D. (1944). Infectious anemias due to Bartonella and related red cell parasites. Trans Am Philos Soc 33, 288-338, 350.

Zachary, J. F. \& Basgall, E. J. (1985). Erythrocyte membrane alterations associated with the attachment and replication of Eperythrozoon suis: a light and electron microscopic study. Vet Pathol 22, 164-170.

Zulty, J. C. \& Kociba, G. J. (1990). Cold agglutinins in cats with haemobartonellosis. J Am Vet Med Assoc 196, 907-910. 